\title{
Discussion of Influence of Equity Incentive of electronics manufacturing industry Listed Companies on Performance
}

\author{
Lijun $\mathrm{Bu}$ \\ School of Accounting, Harbin University of Commerce, Harbin 150028, China \\ bulijun@126.com
}

Keywords: electronics manufacturing industry, equity incentive, performance influence.

\begin{abstract}
In the paper, equity incentive condition of electronics manufacturing industry listed companies from 2009 to 2014 is studied. Related conclusion of equity incentive influence on performance is proposed through analyzing related indicators of equity incentive influence on performance.
\end{abstract}

\section{Definition of electronics manufacturing industry}

Electronics manufacturing industry is a category in the manufacturing industry, which is mainly responsible for producing audio and video products about radio and TV, which are used by individuals and households, mainly including enterprise industries of TV set, DVD player (VCD, SVCD, DVD), video recorder, CD player (CD) and other electronic products. Telephone sets, personal computers, household office equipment, household health care equipment, automotive electronic products, digital cameras, mobile phones, PDA and similar products also belong to production scope of electronics manufacturing industry with the progress of science and technology as well as the emergence of new products and new application.

\section{Implementation of equity incentive in electronics manufacturing industry listed companies}

There are a total of 54 listed companies in China electronics manufacturing industry, such as DEREN, BOE, DMEGC, TCL Group, TDG, etc. A total of 11 electronic manufacturing enterprises proposed equity incentive plans as of December 31, 2014, respectively including DMEGC, HWD, DEREN, Han's Laser, Power Source, JCST, LYRUN MATERIAL, TCL Group, GGEC, Hisense Electric Appliance and BesTV, wherein a total of six companies are implementing and have implemented incentive plans. Related equity incentive information is shown in the following table.

Table 1 Basic information of electronics manufacturing industry listed companies to implement equity incentives

\begin{tabular}{|c|c|c|c|c|c|}
\hline Name & Code & $\begin{array}{l}\text { Date of } \\
\text { releasing } \\
\text { information } \\
\text { for the fist } \\
\text { time }\end{array}$ & $\begin{array}{c}\text { Date of } \\
\text { shareholders' } \\
\text { meeting }\end{array}$ & Event progress & $\begin{array}{l}\text { Incentive } \\
\text { mode }\end{array}$ \\
\hline DEREN & $\begin{array}{c}00205 \\
5\end{array}$ & 2008-09-09 & 2008-09-26 & $\begin{array}{c}\text { In } \\
\text { implementation }\end{array}$ & $\begin{array}{l}\text { Stock } \\
\text { option }\end{array}$ \\
\hline Han's & 00200 & 2012-10-10 & 2012-10-25 & In & Stock \\
\hline $\begin{array}{l}\text { Laser } \\
\text { Power } \\
\text { source }\end{array}$ & $\begin{array}{c}8 \\
60040 \\
5\end{array}$ & 2009-12-10 & 2010-06-28 & $\begin{array}{l}\text { implementation } \\
\text { Completed }\end{array}$ & $\begin{array}{c}\text { option } \\
\text { Restricted } \\
\text { stock }\end{array}$ \\
\hline Corun & $\begin{array}{c}60047 \\
8\end{array}$ & 2008-05-10 & 2008-09-20 & $\begin{array}{c}\text { In } \\
\text { implementation }\end{array}$ & $\begin{array}{l}\text { Stock } \\
\text { option }\end{array}$ \\
\hline $\begin{array}{l}\text { TCL } \\
\text { Group }\end{array}$ & $\begin{array}{c}00010 \\
0\end{array}$ & 2011-01-29 & 2012-01-09 & $\begin{array}{c}\text { In } \\
\text { implementation }\end{array}$ & $\begin{array}{l}\text { Stock } \\
\text { option }\end{array}$ \\
\hline Hisense & 60006 & $2008-11-20$ & 2009-05-12 & Completed & Stock \\
\hline
\end{tabular}




\begin{tabular}{ccc}
\hline Electric & 0 & option \\
Appliance & & \\
\hline
\end{tabular}

(Data source: the data is sorted and obtained from wind database;)

The table shows that more companies adopt stock option mode to implement equity incentives in electronics manufacturing industry because the operation process of targeted placement is much simpler than repurchase in secondary market. It is also the most familiar operation mode in growth process of listed companies.

\section{Influence of electronic manufacturing equity incentives on the performance}

\section{A. Grouping condition}

Equity incentive is a kind of long-term incentive mechanism. Its effect can be displayed for long term. A total of six listed companies were studied, which are implementing or have implemented electronics manufacturing industry incentive till the end of 2014. The basic condition is shown in Table 2:

Table 2 Basic contents of companies which have implemented and are implementing equity incentives in electronics manufacturing industry till the end of 2014.

\begin{tabular}{|c|c|c|c|c|c|c|}
\hline Code & $\begin{array}{l}\text { Brief } \\
\text { name }\end{array}$ & $\begin{array}{l}\text { Declaration } \\
\text { date of } \\
\text { shareholders' } \\
\text { meeting }\end{array}$ & $\begin{array}{l}\text { Incentive } \\
\text { mode }\end{array}$ & Category & $\begin{array}{l}\text { Stock } \\
\text { source }\end{array}$ & $\begin{array}{c}\text { Proportio } \\
\mathrm{n} \text { in total } \\
\text { current } \\
\text { equity } \\
\text { capital }\end{array}$ \\
\hline $\begin{array}{c}00205 \\
5 \\
\end{array}$ & DEREN & 2008-09-26 & $\begin{array}{l}\text { Stock } \\
\text { option }\end{array}$ & Stock A & $\begin{array}{l}\text { Targeted } \\
\text { issuance }\end{array}$ & $0.88 \%$ \\
\hline $\begin{array}{c}00200 \\
8\end{array}$ & $\begin{array}{l}\text { Han's } \\
\text { Laser }\end{array}$ & 2012-10-25 & $\begin{array}{l}\text { Stock } \\
\text { option }\end{array}$ & Stock A & $\begin{array}{l}\text { Targeted } \\
\text { issuance }\end{array}$ & $4.45 \%$ \\
\hline $\begin{array}{c}60040 \\
5\end{array}$ & $\begin{array}{l}\text { Power } \\
\text { source }\end{array}$ & 2010-06-28 & $\begin{array}{l}\text { Restricted } \\
\text { stock }\end{array}$ & Stock A & $\begin{array}{l}\text { Targeted } \\
\text { issuance }\end{array}$ & $4.79 \%$ \\
\hline $\begin{array}{c}60047 \\
8\end{array}$ & Corun & 2008-09-20 & $\begin{array}{l}\text { Stock } \\
\text { option }\end{array}$ & Stock A & $\begin{array}{l}\text { Targeted } \\
\text { issuance }\end{array}$ & $6.29 \%$ \\
\hline $\begin{array}{c}00010 \\
0\end{array}$ & $\begin{array}{l}\text { TCL } \\
\text { Group }\end{array}$ & 2011-01-29 & $\begin{array}{l}\text { Stock } \\
\text { option }\end{array}$ & Stock A & $\begin{array}{l}\text { Targeted } \\
\text { issuance }\end{array}$ & $2.03 \%$ \\
\hline $\begin{array}{c}60006 \\
0\end{array}$ & $\begin{array}{l}\text { Hisense } \\
\text { Electric } \\
\text { Appliance }\end{array}$ & 2009-05-12 & $\begin{array}{l}\text { Stock } \\
\text { option }\end{array}$ & Stock A & $\begin{array}{l}\text { Targeted } \\
\text { issuance }\end{array}$ & $0.99 \%$ \\
\hline
\end{tabular}

(Data source: the data is sorted and obtained through wind database.)

The table shows that Power Source adopts restricted stock plan among companies with final implementation. Net profit growth rate is the performance condition measurement indicator set by major shareholders for stock transfer. However, other companies select stock option. The set performance measurement indicators also respectively include net profit growth rate, net assets yield index and other indicator requirements.

Electronics manufacturing industry listed companies are divided into two groups according to the condition whether the company implemented equity incentives or not from 2009 to 2014 . We set the companies implementing equity incentive as group $\mathrm{A}$, and other companies without implementation of equity incentive are listed as control group B. There were always three companies in group A from 2009 to 2010, respectively including DEREN, Corun and Hisense Electric Appliance. The control group B contained 51 companies. Group A contained four companies, respectively including DEREN, Corun, Hisense Electric Appliance and Power Source, and corresponding group B included 50 
companies till 2011. Group A contained five companies till 2012, TCL Group was increased compared with that in 2011, and corresponding group B contained 49 companies. The condition in 2013 was the same as that in 2014, group A contained six companies, and Han's Laser was increased compared with that in 2011, and corresponding group B contained 48 companies.

B. Determination of performance indicators

Since listed companies aiming at electronics manufacturing industry are selected for analysis, many external factors have the same influence on the whole industry, such as macroeconomic influence, industry overall development trend and industry policy, it can be concluded that economic environment change and industry factors are controlled to a certain extent. When company operating performance is comparatively analyzed, suitable performance indicators should be selected. Commonly used performance indicators mainly include: earnings per share, return rate on net assets, operating profit, net profit attributable to the parent company owners and other indicators. Indicator 1 : Earnings per share EPS

Earnings per share (EPS) are used for reflecting the operating results of an enterprise as a listed company. It is equal to the enterprise's annual net income which is divided by common stock quantity issued outside the company. The profit level and investment risk of common stock are measured. Investors, creditors and other information users evaluate profit ability of the enterprise accordingly, and it is an important financial indicator for predicting the enterprise's growth potential, and making related economic decision.

Indicator 2: net assets return rate after deduction of non-recurring gains and losses

Net assets return rate after deduction of non-recurring gains and losses is used for reflecting the profitability of the enterprise. It is equal to the ratio between net profit and enterprise net assets after reduction of non-recurring gains and losses. It is a comprehensive indictor, which can reflect the enterprise's profitability, capital structure quality and capital operation efficiency. It is also one of the indicators which are mainly considered by investors.

Indicator 3: Operating profit

Operating profit is the profit obtained by the enterprise engaged in production and business operation activities within certain accounting period. It is main source of enterprise profits. Operating profit is equal to the net amount after operating cost, business tax and surcharges, marketing fees, management fees and financial fee asset impairment loss are reduced from enterprise operating income, and fair value change gains and losses as well as investment returns are added. Operating profit is an important indicator to measure enterprise's actual profitability. Influence of enterprise non-recurring gains and losses on enterprise net profit is deducted, and improvement of enterprise main business income is an important mode to improve profitability.

Indicator 4: net profit attributable to the parent company

Net profit attributable to shareholders of the parent company refers to the remaining net profits belonging to common shareholders of the parent company after reduction of interests and losses of a few shareholders. It is one of the most concerned indicators for company shareholders.

1) Analysis on performance indicator condition

We divide electronics manufacturing industry listed companies into two groups according to implementation of equity incentive or not. Performance average value comparative analysis condition of the listed companies in all groups from 2009 to 2014 is shown in Table 3-5.

Table 3 Annual average value of performance indicators in Group A and Group B

\begin{tabular}{cccccccc}
\hline $\begin{array}{c}\text { Performance } \\
\text { indicator }\end{array}$ & $\begin{array}{c}\text { Implemented } \\
\text { or not }\end{array}$ & $\begin{array}{c}\text { Year of } \\
2009\end{array}$ & $\begin{array}{c}\text { Year of } \\
2010\end{array}$ & $\begin{array}{c}\text { Year of } \\
2011\end{array}$ & $\begin{array}{c}\text { Year of } \\
2012\end{array}$ & $\begin{array}{c}\text { Year of } \\
2013\end{array}$ & $\begin{array}{c}\text { Year of } \\
2014\end{array}$ \\
\hline $\begin{array}{c}\text { Earnings per } \\
\text { share }\end{array}$ & $\begin{array}{c}\text { Implemented } \\
\text { (A) }\end{array}$ & 0.1932 & 0.4384 & 0.4038 & 0.5340 & 0.3418 & 0.4230 \\
$\begin{array}{c}\text { (Yuan) } \\
\text { Not } \\
\text { implemented } \\
\text { (B) }\end{array}$ & -0.0653 & -0.0558 & 0.2003 & 0.2510 & 0.0865 & 0.2615 \\
Net assets & Implemented & 7.3500 & 9.6533 & 11.8750 & 7.8100 & 9.0400 & 11.2430 \\
\hline
\end{tabular}




\begin{tabular}{|c|c|c|c|c|c|c|c|}
\hline $\begin{array}{l}\text { return rate } \\
(\%)\end{array}$ & $\begin{array}{c}\text { (A) } \\
\text { Not } \\
\text { implemented } \\
\text { (B) }\end{array}$ & -3.5200 & -8.4808 & 5.3384 & 9.0921 & -0.3166 & -2.0720 \\
\hline $\begin{array}{l}\text { Operating } \\
\text { profit }\end{array}$ & $\begin{array}{l}\text { Implemented } \\
\text { (A) }\end{array}$ & 2710.50 & $\begin{array}{c}17270.0 \\
0\end{array}$ & $\begin{array}{c}26288.5 \\
0\end{array}$ & $\begin{array}{c}63835.2 \\
0\end{array}$ & $\begin{array}{c}45322.5 \\
0\end{array}$ & $\begin{array}{c}74646.1 \\
7\end{array}$ \\
\hline $\begin{array}{l}\text { (ten } \\
\text { thousand } \\
\text { Yuan) }\end{array}$ & $\begin{array}{l}\text { Not } \\
\text { implemented } \\
\text { (B) }\end{array}$ & $\begin{array}{c}-2188.7 \\
4\end{array}$ & -8385.69 & $\begin{array}{c}14665.9 \\
1\end{array}$ & $\begin{array}{c}15775.2 \\
1\end{array}$ & 5763.76 & $\begin{array}{c}22482.4 \\
4\end{array}$ \\
\hline $\begin{array}{l}\text { Net profit } \\
\text { attributable } \\
\text { to the parent } \\
\text { company } \\
\text { (ten } \\
\text { thousand } \\
\text { Yuan) }\end{array}$ & $\begin{array}{l}\text { Implemented } \\
\text { (A) } \\
\text { Not } \\
\text { implemented } \\
\text { (B) }\end{array}$ & $\begin{array}{c}3116.00 \\
-1338.8 \\
5\end{array}$ & $\begin{array}{c}18298.0 \\
0 \\
-2393.51\end{array}$ & $\begin{array}{c}24159.7 \\
5 \\
14959.4 \\
1\end{array}$ & $\begin{array}{c}38353.2 \\
0 \\
15961.9 \\
1\end{array}$ & $\begin{array}{c}51301.6 \\
7 \\
7796.41\end{array}$ & $\begin{array}{c}86839.8 \\
3 \\
21081.5 \\
6\end{array}$ \\
\hline
\end{tabular}

(Data source: data are sorted and obtained through Eastmoney)

We comparatively analyzed change condition of difference of all performance indicators among companies in two groups from 2009 to 2014. Concrete conditions are shown in the following table:

\begin{tabular}{|c|c|c|c|c|c|c|}
\hline $\begin{array}{c}\text { Performance } \\
\text { indicators }\end{array}$ & $\begin{array}{c}\text { Year of } \\
2009\end{array}$ & $\begin{array}{c}\text { Year of } \\
2010\end{array}$ & $\begin{array}{c}\text { Year of } \\
2011\end{array}$ & $\begin{array}{c}\text { Year of } \\
2012\end{array}$ & $\begin{array}{c}\text { Year of } \\
2013\end{array}$ & $\begin{array}{c}\text { Year of } \\
2014\end{array}$ \\
\hline $\begin{array}{c}\text { Earnings per } \\
\text { share-dilutio } \\
\text { n (Yuan) }\end{array}$ & 0.2585 & 0.4942 & 0.2035 & 0.283 & 0.2553 & 0.1615 \\
\hline $\begin{array}{l}\text { Net assets } \\
\text { return rate } \\
(\%)\end{array}$ & 10.87 & 18.1341 & 6.5366 & -1.2821 & 9.3566 & 13.315 \\
\hline $\begin{array}{c}\text { Operating } \\
\text { profit } \\
\text { (ten thousand } \\
\text { Yuan) }\end{array}$ & $\begin{array}{c}4899.2 \\
4\end{array}$ & $\begin{array}{l}25655.6 \\
9\end{array}$ & $\begin{array}{c}11622.5 \\
9\end{array}$ & $\begin{array}{c}48059.9 \\
9\end{array}$ & $\begin{array}{c}39558.7 \\
4\end{array}$ & $\begin{array}{c}52163.7 \\
3\end{array}$ \\
\hline $\begin{array}{l}\text { Net profits } \\
\text { attributable to } \\
\text { the parent } \\
\text { company (ten } \\
\text { thousand } \\
\text { Yuan) }\end{array}$ & $\begin{array}{c}4454.8 \\
5\end{array}$ & $\begin{array}{c}20691.5 \\
1\end{array}$ & 9200.34 & $\begin{array}{c}22391.2 \\
9\end{array}$ & $\begin{array}{c}43505.2 \\
6\end{array}$ & $\begin{array}{c}65758.2 \\
7\end{array}$ \\
\hline
\end{tabular}

(Data source: the data is sorted and obtained through Eastmoney)

Table 3 shows the performance indicator of electronics manufacturing industry listed companies from 2009 to 2014. Earnings per share show that the average value of group A from 2009 to 2014 was respectively 0.1932 Yuan, 0.4384 Yuan, 0.4038 Yuan and 0.5340 Yuan, 0.3418 Yuan and 0.4230 Yuan. The average value of Group B was respectively -0.0653 Yuan, -0.0558 Yuan, 0.2003 Yuan, 0.2510 Yuan, 0.0865 Yuan and 0.2615 Yuan. Net assets return rate of group A was respectively 7.35\%, 9.6533\%, 11.875\%, 7.81\%, 9.04\% and 11.24\%. The return rate of group B was respectively $-3.52 \%,-8.4808 \%, 5.3384 \%, 9.0921 \%,-0.3166 \%$ and $2.07 \%$; The operating profit of group A was respectively 27.105 million Yuan, 172.7 million Yuan, 262.885 million Yuan, 638.352 million Yuan, 453.225 million Yuan, 746.462 million Yuan. The operating profit of group B was respectively -21.8874 million Yuan, -83.8569 million Yuan, 146.6591 million Yuan, 157.7521 million Yuan, 
57.6376 million Yuan and 224.824 million Yuan; Net profit attributable to the parent company of group A was respectively 31.16 million Yuan, 182.98 million Yuan, 241.5975 million Yuan, 383.532 million Yuan, 513.0167 million Yuan and 868.398 million Yuan. Net profit attributable to the parent company of group B was respectively -13.3885 million Yuan, 23.9351 million Yuan, 149.5941 million Yuan, 159.6191 million Yuan, 77.9641 million Yuan and 210.816 million Yuan. We can observe that all performance indicators of listed companies in group A was greatly better than that of listed companies in group B since 2009 according to comparison condition of performance indicators.

Table 4 shows the difference of all performance indicators in two groups from 2009 to 2014 . Performance of group A was always better than the company without implementation of equity incentives, wherein the difference in operating profit and net profit attributable to the parent company was larger and larger. The operating profit difference was increased from 48.9924 million Yuan in 2009 to 521.6373 million Yuan in 2014. It is obvious that the performance improvement condition of group A was greatly better than that of group B. Earnings per share show that the performance indicator difference of group A and group B was always stable from 2009 to 2014, which was always kept between 0.25 and 0.5 . Net assets return rate shows that the performance of group A was basically better than that of group B prominently. Though it was reflected as a fluctuation form in the difference table, the excellence of group A still can be better embodied. Performance indicators of group A and group B as well as comparative analysis on difference between group A and group B show that listed companies in group A implementing equity incentives was far better than group B without implementation of equity incentives.

2) Analysis on performance growth rate indicator condition

Performance indicator is used for measuring financial condition and operating results of enterprises, which can reflect the difference of performance between different enterprises. However, performance indicators are influenced by many factor, such as own scale and development condition of the company. Difference in business performance is not completely produced by equity incentives. Therefore, it is not convincing enough if the difference in performance indicators between two groups is regarded as result of equity incentives.

Therefore, performance growth rate indicator is also selected as supplement in the paper. Performance growth rate indicator is used for measuring development and change condition of company performance. Influence of company own asset scale difference on company performance is overcome by selection of these indicators, and long-term increase ability of the enterprise is reflected. Annual average growth rate of all performance indicators of the companies in two companies from 2009 to 2014 is reflected in the following table.

Table 5 Annual average growth rate condition of performance indicators in two groups from 2009 to 2014

\begin{tabular}{lcc}
\hline Performance indicator & $\begin{array}{c}\text { Implemented } \\
\text { (A) }\end{array}$ & $\begin{array}{c}\text { Not } \\
\text { implemented } \\
\text { (B) }\end{array}$ \\
\hline $\begin{array}{l}\text { Earnings per } \\
\text { share-dilution }\end{array}$ & $27.8 \%$ & $-62.28 \%$ \\
Net assets return rate & $12.05 \%$ & $-113.12 \%$ \\
$\begin{array}{l}\text { Operating profit } \\
\text { Net profits attributable }\end{array}$ & $153.58 \%$ & $48.48 \%$ \\
to the parent company & $136.21 \%$ & $154.43 \%$ \\
\hline
\end{tabular}

(Data source: the data is sorted and obtained through Eastmoney.)

Table 5 shows that the annual average growth rate of all performance indicators in group A implementing equity incentives was higher than group B without implementation of equity incentives. The annual average growth rate of earnings per share in group A from 2009 to 2014 was 27.8\%, annual average growth rate of earnings per share in group B was $-62.28 \%$. The annual average growth rate of net asset return rate operating profit in group A was 12.05\%, and annual average growth rate of net asset return rate operating profit in group B was $-113.12 \%$. The annual average growth rate in 
group A was $153.58 \%$. The annual average growth rate in group B was $48.48 \%$; the average annual growth rate of net profit attributable to the parent company in group A was $136.21 \%$. The average annual growth rate of net profit attributable to the parent company in group B was $154.43 \%$. Performance indicators and performance growth rate indicators in the two groups, especially performance growth rate indicators, are considered. We can conclude that equity incentive implementation can play the role of promoting company performance to certain extent.

\section{Conclusion}

Overall condition of electronic manufacturing listed companies in China shows that shares for equity incentives account for lower proportion in total equity of the company. Six companies in group A respectively include the follows: $0.88 \%$ for DEREN, $4.45 \%$ for Han's Laser, $4.79 \%$ for Power source, 6.29\% for Corun, 6.29\% for TCL Group and 0.99\% for Hisense Electric Appliance, the proportions are far lower than that in foreign listed companies on one hand, they are also lower than $10 \%$ level as the highest limit regulated in China 'Listed Company Equity Incentive Measures (Trial)'. However, the share proportion for equity incentive in the listed companies is lower, which is far lower than the best level for promoting company performance. Therefore, the promotion role of equity incentive on company performance is not exerted to the largest extent. Listed companies should further improve the share level for equity incentive.

\section{References}

[1]. Fan Hejun, Chu Zihao. Inverted U-shaped performance of equity incentive on company performance [J]. Economics and Management Research. 2013, (02):5 11;

[2]. Fu Dong. Study on the relationship between equity incentive contract design and company performance [J]. Enterprise economy. 2013, (3):173 176;

[3]. Lin Peng,Ailsa Roell.Managerial Incentives and Stock Price Manipulation[J].The Journal of Finance, 2014, Vol.69 (2)

[4]. Chen Biao,Li Jianxin.The Effects of Equity Incentive on the Performance of Listed Companies in Chinese Stock Market[J]. Operations Research and Fuzziology, 2015, Vol.05 (02):23-29

[5]. Chang Qicheng,Gao Yan. Relationship between Equity Incentive of Listed Companies on Growth Enterprise Market and the Performance of Company-Review and Evaluation[J]. Management Science and Engineering, 2015, Vol.04 (03):57-62 